\title{
Augmentation of chemically induced pancreatic and bronchial cancers by epidermal growth factor
}

\author{
R A MALT, J F CHESTER, H A GAISSERT, AND J S ROSS \\ From the Surgical Services, Shriners Burns Institute and Massachusetts General Hospital, the Department of \\ Surgery, Harvard Medical School, Boston, Massachusetts, and the Department of Pathology, University of \\ Massachusetts at Berkshire Medical Center, Pittsfield, Massachusetts, USA.
}

SUMMARY The incidence of Syrian golden hamsters with pancreatic cancer induced by subcutaneous injections of $N$-nitroso-bis(2-oxopropyl)amine for 19 weeks (each $10 \mathrm{mg} / \mathrm{kg}$ ) increased from $44 \%$ to $75 \%(\mathrm{p}=0.016)$ when epidermal growth factor was also administered from week 5 through week $8(5 \mu \mathrm{g}$ every three days for 10 injections). Epidermal growth factor increased pancreatic weight and body weight. The incidence of animals with bronchial cancer doubled. Epidermal growth factor could be a cocarcinogen as a result of its mitogenic activity.

Proliferation of new cell populations is required for carcinogenesis and promotes it. ${ }^{12}$ Because the polypeptide hormone epidermal growth factor (EGF) is ordinarily mitogenic, EGF augments neoplasia. ${ }^{3}$ In mice, EGF shortens the latent period of development of methylcholanthrene-induced cutaneous cancer ${ }^{4}$ and increases by three-fold the number of anal squamous cancers after administration of the colonic carcinogen 1,2-dimethylhydrazine (DMH). ${ }^{5}$ Reduction of the salivary-enteric complement of EGF in male mice by removal of the submandibular salivary glands, with their rich store of EGF and other growth factors, is associated with a one third reduction in the number of animals with colonic cancers after 20 weeks of treatment with DMH. ${ }^{6}$

The experiments to be described examined the effect of EGF on pancreatic cancer induced in hamsters by $N$-nitroso-bis(2-oxopropyl)amine (BOP). ${ }^{7}$ Hamster liver converts BOP to $N$-nitroso(2hydroxypropyl)(2-oxopropyl)amine (HPOP), which is apparently . the proximate carcinogen. ${ }^{8}$ BOPinduced pancreatic cancers, arising mainly in association with ductal goblet cells, ${ }^{9}$ are similar to human pancreatic cancers in terms of their histology, distribution, and multiplicity; production of diabetes and thromboses; and presence of immunologic and enzymic markers. ${ }^{1011}$ Unlike human carcinomas, they arise in pancreatic acini as well as in ducts.

\section{Methods}

\section{ANIMALS}

Female Syrian golden hamsters were divided among four treatment groups. The ratio of survivors to the initial numbers of animals is indicated in parentheses: EGF + BOP (32/45), BOP alone (25/25), EGF alone $(10 / 10)$, saline solution $(9 / 10)$. Animals receiving BOP were given subcutaneous injections for 19 weeks $(10 \mathrm{mg} / \mathrm{kg})$. Epidermal growth factor was administered every three days for a course of 10 injections (each $5 \mu \mathrm{g}$ ) (Figure). Pancreatic cancers were diagnosed by standard criteria. ${ }^{12}$

\section{Results}

The Figure shows that hamsters receiving EGF alone were heavier by $24-36 \%$ than all other groups at the end of the experiment. The heaviest pancreases per gram of body weight were found in animals given EGF alone and in those given EGF + BOP. The increments were $44 \%$ greater than values in the saline-injected control group and $22 \%$ greater than values in the BOP group. Details are reported in reference? ${ }^{7}$.

Increased cellularity and an increased number of cancers were observed in the EGF-BOP group. The Table shows the attack rates.

\section{Discussion}

A cocarcinogenic effect of EGF in these experiments 


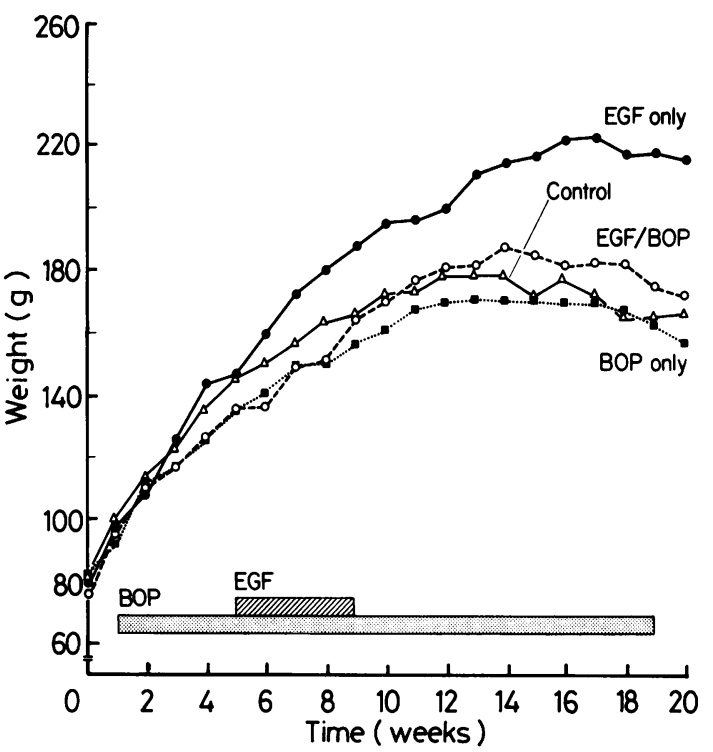

Figure Body weight of EGF-treated hamsters during 19 weeks of BOP treatment. Reproduced by permission of Cancer Research, ref. 7.

nearly doubles the incidence of pancreatic and bronchial cancers induced by BOP. The conditions did not permit discriminating between an effect of EGF on initiation or on promotion of neoplasia nor on stimulation of RNA synthesis or DNA synthesis. ${ }^{13}$

Neither is it possible in considering the pancreatic weights of hamsters treated with EGF to separate the contributions of increased cellularity, of a generalized effect on visceral mass, or of the mass of the cancers themselves. In view of the mitogenic action of EGF on myriad cells and organs, ${ }^{37}$ including pancreas and cultured pancreatic cancer cells, in the present experiments, a direct stimulatory effect on pancreatic cell proliferation seems likely. The trophic effect of cholecystokinin on the hamster pancreas can increase by six-fold the number of animals with BOP-induced carcinomas. ${ }^{14}$ But absence of a cocarcinogenic effect of caerulein (an analogue of cholecystokinin) in hamsters treated with the carcinogen $N$-nitrosobis (2hydroxypropyl)amine is not easy to rationalise with these results. ${ }^{15}$ Moreover, human cancers are more frequent as body weight increases, ${ }^{16}$ and azoxymethane-induced colonic carcinogenesis in rats is inhibited by severe weight loss. ${ }^{1718}$ The cocarcinogenic effect of EGF observed on bronchial carcinoma in our hamsters is not within the scope of this report.

Do the results of these experiments have counterparts in natural carcinogenesis? In mice, the pancreas is the richest source of mRNA for prepro-EGF, except for the kidney and the unique circumstances of the lactating breast and the submandibular glands. ${ }^{19}$ Exposure of human KB carcinoma cells to EGF increases the levels of their own EGF-receptor mRNA and protein at a post-transcriptional level. ${ }^{20}$ Epidermal growth factor binds to receptors on cultured human pancreatic cells ${ }^{21}$ and can stimulate phosphorylation of membrane proteins. ${ }^{22}$ Although the presence of an endogenous mitogen is far from proving the existence of autocrine regulation, ${ }^{23}$ especially inasmuch as any EGF secreted by the pancreas could be used strictly for exocrine purposes, the possibility exists. The EGF receptor is the cellular homologue of the avian erythroblastosis virus $\operatorname{erb} B$ proto-oncogene, ${ }^{24} 25$ and the genes for pancreatic neuropeptide $\mathrm{Y}$ and $\operatorname{erbB}$ overlap on human chromosome 7. ${ }^{26}$ Perhaps endogenous EGF enhances expression of the surface receptors on the cells to which EGF binds, ${ }^{27}$ leading to greater susceptibility to chemical carcinogenesis. ${ }^{28} 29$

Presented at the Third International Conference on Intestinal and Pancreatic Adaptation, Entero Pancreatic Adaptation: New Approaches, Titisee, West Germany, 11-14 June 1986. Supported by NIH grant CA-43906.

Table Incidence of cancers after BOP treatment

\begin{tabular}{|c|c|c|c|c|}
\hline Treatment & $\begin{array}{l}\text { Animals } \\
\text { (no) }\end{array}$ & $\begin{array}{l}\text { Pancreatic cancers, } \\
\text { local or invasive } \\
(\% \text { of animals })\end{array}$ & $\begin{array}{l}\text { Pancreatic cancers, } \\
\text { invasive } \\
\text { (\% of those animals } \\
\text { having cancer) }\end{array}$ & $\begin{array}{l}\text { Bronchial } \\
\text { cancers } \\
(\% \text { of animals })\end{array}$ \\
\hline EGF & 10 & 0 & 0 & 0 \\
\hline BOP & 25 & 44 & 73 & 28 \\
\hline EGF/BOP & 32 & $75^{*}$ & $63 \dagger$ & $56 \ddagger$ \\
\hline Controls & 9 & 0 & 0 & 0 \\
\hline Total & 76 & 46 & 66 & 33 \\
\hline
\end{tabular}

Comparison with BOP group:

$\chi^{2}=5.69, \mathrm{p}=0.016 ; \dagger \chi^{2}=1 \cdot 29, \mathrm{p}=0.26 ; \ddagger \chi^{2}=4.55, \mathrm{p}=0.03$.

Local cancers were confined to the pancreas. Invasive cancers infiltrated peripancreatic fat, connective tissue, or lymph nodes. 


\section{References}

1 Scarpelli DG, Rao MS, Subbarao V. Augmentation of carcinogenesis by $N$-nitrosobis(2-oxopropyl)amine administered during $\mathrm{S}$ phase of the cell cycle in regenerating hamster pancreas. Cancer Res 1983; 43: 611-6.

2 Rotstein J, Sarma DSR, Farber E. Sequential alterations in growth control and cell dynamics of rat hepatocytes in early precancerous steps in hepatocarcinogenesis. Cancer Res 1986; 46: 2377-85.

3 Stoschek CM, King LE Jr. Role of epidermal growth factor in carcinogenesis. Cancer Res 1986; 46: 1030-7.

4 Rose SP, Stahn R, Passovoy DS, Herschman H. Epidermal growth factor enhancement of skin tumor induction in mice. Experientia 1976; 32: 913-5.

5 Kingsnorth AN, Abu-Khalaf M, Ross JS, Malt RA. Potentiation of 1,2-dimethylhydrazine-induced anal carcinoma by epidermal growth factor in mice. Surgery 1985; 97: 696-700.

6 Li AKC, Schattenkerk ME, deVries JE, Ross JS, Malt RA. Saliva as a modifier of dimethylhydrazine-induced colorectal cancer. In: Malt RA, Williamson RCN, eds. Colonic carcinogenesis: Falk Symposium 31, Lancaster: MTP Press Ltd, 1981: 261-71.

7 Chester JF, Gaissert HA, Ross JS, Malt RA. Pancreatic cancer in the Syrian hamster induced by $N$-nitroso-bis(2oxopropyl)amine: Cocarcinogenic effect of epidermal growth factor. Cancer Res 1986; 46: 2954-70.

8 Kokkinakis DM, Scarpelli DG, Rao MS, Hollenberg PF. Metabolism of pancreatic carcinogens $N$-nitroso2,6-dimethylmorpholine and $N$-nitrosobis(2-oxopropyl)amine by microsomes and cytosol of hamster pancreas and liver. Cancer Res 1983; 43: 5761-7.

9 Ishikawa O, Wada A, Oohigashi H, Imaoka S, Iwanaga T. Relationship between goblet cells and carcinoma of the pancreas during $N$-nitrosobis(2-hydroxypropyl)amine-induced carcinogenesis in Syrian golden hamsters. Cancer Res 1984; 44: 1630-4.

10 Pour PM, Runge RG, Birt D, Gingell R, Lawson T, Nagel D, Wallcave L, Salmasi SZ. Current knowledge of pancreatic carcinogenesis in the hamster and its relevance to the human disease. Cancer 1981; 47: 157387.

11 Townsend CM Jr, Franklin RB, Gelder FB, Glass E, Thompson JC. Development of a transplantable model of pancreatic duct adenocarcinoma. Surgery 1982; 92: $72-8$.

12 Cubilla AL, Fitzgerald PJ. Classification of pancreatic cancer. Mayo Clin Proc 1979; 54: 449-58.

13 Wakshull EM, Wharton W. Stabilized complexes of epidermal growth factor and its receptor on the cell surface stimulate RNA synthesis but not mitogenesis. Proc Natl Acad Sci USA 1985; 82: 8513-7.
14 Howatson AG, Carter DC. Pancreatic carcinogenesisenhancement by cholecystokinin in the hamster-nitrosamine model. Br J Cancer 1985; 51 : 107-14.

15 Andrén-Sandberg $\AA$, Dawiskiba S, Ihse I. Studies of the effect of cerulein administration on experimental pancreatic carcinogenesis. Scand J Gastroenterol 1984; 19: 122-8.

16 Lew EA, Garfinkel L. Variations in mortality by weight among 750,000 men and women. J Chronic Dis 1979; 32: 563-76.

17 Williamson RCN, Bauer FLR, Terpstra OT, Ross JS, Malt RA. Contrasting effects of subtotal enteric bypass, enterectomy, and colectomy on azoxymethane-induced intestinal carcinogenesis. Cancer Res 1980; 40: 538-43.

18 Bristol JB, Wells M, Williamson RCN. Adaptation to jejunoileal bypass promotes experimental colorectal carcinogenesis. Br J Surg 1984; 71 : 123-6.

19 Rall LB, Scott J, Bell GI, Crawford RJ, Penschow JD, Niall HD, Coghlan JP. Mouse prepro-epidermal growth factor synthesis by kidney and other tissues. Nature 1985; 313: 228-31

20 Clark AJL, Ishii S, Richert N, Merlino GT, Pastan I. Epidermal growth factor regulates the expression of its own receptor. Proc Natl Acad Sci USA 1985; 82: 8374 8.

21 Korc M, Magun BE. Recycling of epidermal growth factor in a human pancreatic carcinoma cell line. Proc Natl Acad Sci USA 1985; 82: 6172-5.

22 Hierowski MT, Liebow C, du Sapin K, Schally AV. Stimulation by somatostatin of dephosphorylation of membrane proteins in pancreatic cancer MIA $\mathrm{PaCa}-2$ cell line. FEBS Lett 1985; 179: 252-6.

23 Sporn MB, Roberts AB. Autocrine growth factors and cancer. Nature 1985; 313: 745-7.

24 Weinberg RA. The action of oncogenes in the cytoplasm and nucleus. Science 1985; 230: 770-6.

25 Downward J, Yarden Y, Mayes E, Scrace G, Totty N, Stockwell P, Ullrich A, Schlessinger J, Waterfield MD. Close similarity of epidermal growth factor receptor and V-erb-B oncogene protein sequences. Nature 1984; 307: 521-7.

26 Takeuchi T, Gumucio DL, Yamada T, Meisler MH, Minth CD, Dixon JE, et al. Genes encoding pancreatic polypeptide and neuropeptide $\mathrm{Y}$ are on human chromosomes 17 and 7. J Clin Invest 1986; 77: 1038-41.

27 Earp HS, Austin KS, Blaisdell J, Rubin RA, Nelson KG, Lee LW, Grisham JW. Epidermal growth factor (EGF) stimulates EGF receptor synthesis. $J$ Biol Chem $1986 ; 261$ : 4777-80.

28 Müller R. Proto-oncogenes and differentiation. Trends Biochem Sci 1986; 11: 130-3.

29 Goustin AS, Leof EB, Shipley GD, Moses HL. Growth factors and cancer. Cancer Res 1986; 46: 1015-29. 